\title{
IMPLEMENTASI KONSEP MASLAHAH MURSALAH DALAM MEKANISME PASAR
}

\author{
Ziyadatus Shofiyah dan M. Lathoif Ghozali \\ Universitas Islam Negeri Sunan Ampel Suarabaya \\ Email: ziyahshofiyah@gmail.com dan muhammadlathoif@gmail.com
}

\begin{abstract}
This article aims to find out the relationship between maslahah mursalah and market mechanisms at the time of the Prophet and the present. This study uses a library research method with a descriptive approach. At the time of the Prophet Muhammad refused to intervene in prices because the price in the market was based on natural market mechanisms. Prices in effect at that time are based on supply and demand. However, Ibn Taimiyah allowed the government to intervene in prices at this time, such as when there was collusion between sellers, monopolies, and community needs were threatened. The government has a share in determining prices at certain times. Ibn Taymiyyah allowed price intervention as a form of benefit for mankind and prevented negative things that would be felt by both sellers and buyers.
\end{abstract}

Keywords: Maslahah Mursalah, Market Mechanism, and Price Intervention.

\begin{abstract}
Abstrak
Artikel ini bertujuan untuk menemukan tentang keterkaitan antara maslahah mursalah dengan mekanisme pasar pada masa Rasulullah dan masa sekarang. Penelitian ini menggunakan metode penelitian library research dengan pendekatan deskriptif. Rasulullah pada zamannya menolak melakukan intervensi harga dikarenakan harga yang berlaku pada pasar berdasarkan mekanisme pasar alami. Harga yang berlaku pada saat itu berdasarkan suplay dan demand. Namun, Ibnu Tamiyah memperbolehkan pemerintah melakukan intervensi harga pada saat ini seperti ketika terjadinya kolusi antar penjual, monopoli, dan terancamnya kebutuhan masyarakat. Pemerintah mempunyai andil dalam penentuan harga di saat-saat tertentu. Diperbolekannya intervensi harga oleh ibnu taimiyah adalah merupakan bentuk kemaslahatan umat manusia dan menjaga agar tidak terjadi hal-hal negatif yang akan dirasakan oleh penjual maupun pembeli.
\end{abstract}

Kata Kunci: Maslahah Mursalah, Mekanisme Pasar, dan Intervensi Harga. 


\section{PENDAHULUAN}

Hukum islam merupakan syariat yang diturunkan oleh Allah SWT untuk kemaslahatan umat manusia. Hukum islam pada dasanya sebagai kebaikan hidup individu maupun sosial (Cholili, 2013) Allah SWT mengutus para Rasul sebagai petunjuk jalan kebaikan dan keburukan untuk umat manusia. seperti yang telah dikutip oleh Fahlefi pada Asy-Syatibi mengatakan, bahwa apapun yang diajarkan oleh agama islam semata-mata bertujuan untuk kesejahteraan hidup umat manusia baik di dunia maupun di akhirat kelak (Fahlefi, 2016).

Maslahah Mursalah adalah Metode penegakan hukum yang sangat efektif dalam merespon dan memberikan Solusi, seperti yang dilakukan oleh nabi Muhammad, sahabat, tabi'in dan para ulama' (Asriaty, 2015).

Pembahasan maslahah mursalah ini sangat penting, sebab dapat dikatakan bahwa maslahah mursalah tesebut sebagai pondasi bangunan syariat agama islam yang ditujukan untuk kepentingan umat manusia sebagai hamba Allah dalam menyangkut kehidupan dunia maupun akhiratnya (Asmawi, 2014). Salah satu kemaslahatan umat manusia yaitu mengenai konsep ekonomi. Ekonomi merupakan kegiatan yang tidak terlepas dalam kehidupan seharihari. Agama islam mempunyai pandangan positif mengenai aktivitas ekonomi. Semakin banyaknya manusia yang berkontribusi dalam aktivitas ekonomi, maka akan semakin baik dalam tujuan maupun prosesnya. Dalam hal ini, aktivitas ekonomi berdasarakn ajaran yang telah ditetapkan agama islam. Ketakwaan seorang hamba kepada Tuhan-Nya akan membawa seseorang tersebut untuk melakukan kegiatan yang lebih produktif (Ilyas, 2015).

Salah satu aktivitas ekonomi yaitu mekanisme pasar. Mekanisme pasar merupakan Interaksi antara permintaan konsumen (suplay) dan penawaran produsen (demand). Oleh karena itu, tingkat harga merupakan kombinasi dari kekuatan penawaran dan permintaan. Perilaku penawaran dan permintaan adalah konsep dasar dari kegiatan ekonomi yang lebih luas (Mursal, 2018).

Pada aktivitas jual beli, islam tidak melarang individu untuk mendapatkan keuntungan dari penjualan tersebut. Namun, besarnya keuntungan terkadang tidak sesuai dengan kemampuan daya beli masyarakat. Sehingga harga pada pasar tersebut akan menimbulkan masalah. Pada hal ini, mekanisme pasar akan mampu mengatur dalam mencapai keseimbangan pasar (Saleh, 2011).

Pada kajian ini, penulis mengambil tema tentang "implementasi maslahah mursalah dalam mekanisme pasar". Fokus materi ini yaitu mengenai keterkaitan antara maslahah mursalah dengan mekanisme pasar pada masa Rasulullah dan masa sekarang. Pembahasan ini mengenai intervensi pasar yang tidak dilakukan oleh Rasulullah SAW pada zaman dahulu namun dilakukan pada masa sekarang.

\section{LITERATUR REVIEW}

Pada penelitian ini, peneliti membandingkan dengan penelitian terdahulu sebagai rujukan yang akan dibahas dalam materi ini dan sebagai rujukan pada penelitian ini. Terdapat beberapa penelitian yang berkaitan dengan materi ini, di antaranya:

1. Mabarroh Azizah, (2012), "Harga Yang Adil Dalam Mekanisme Pasar Dan Peran Pemerintah Dalam Perspektif Islam", jenis dari penelitian ini menggunakan metode kepustakanaan atau library research. Hasil dari penelitian ini yaitu, harga Adil adalah harga tetap, dan disebut juga sebagai harga yang sama. Harga ini dihasilkan 
oleh pasar yang adil, oleh penawaran dan permintaan yang adil. Partisipasi negara atau pemerintah di sini hanya akan dibenarkan jika terjadi ketidakstabilan Muncul, maka pemerintah harus menentukan harga untuk mempertahankan kepentingan publik serta menghindari penimbunan dan ketidakadilan.

Berdasarkan uraian tersebut keterkaitan penelitian ini dan penelitian terdahulu yaitu, pada kedua penelitian tersebut mempunyai persamaan mengenai mekanisme pasar yang adil dalam islam, namun pada penelitian terdahulu tidak membahas mengenai maslahah mursalahnya. Pada artikel ini bertujuan untuk menemukan tentang keterkaitan antara maslahah mursalah dengan mekanisme pasar pada masa Rasulullah dan masa sekarang, sedangkan pada pada penelitian terdahulu tersebut mempunyai tujuan untuk mengetahui harga yang adil dan teori harga dalam pandangan islam.

2. Euis Amalia, (2013), "Mekanisme Pasar Dan Kebijakan Penetapan Harga Adil Dalam Perspektif Ekonomi Islam", jenis dari penelitian ini menggunakan metode kepustakanaan atau library research, hasil dari penelitian ini yaitu, konsep Ekonomi Islam menegaskan bahwa mekanisme pasar dan penetapan harga perlu diatur untuk mene-gakkan keseimbangan pasar dan keadilan ekonomi dengan memper-timbangkan kepentingan para pihak yang terlibat di pasar. Manakala terjadi tindakantindakan yang bersifat zhulm sehingga terjadi distorsi pasar atau harga tidak berada pada titik keseimbangannya, pemerintah sangat berperan untuk mengambil kebijakan berupa penetapan harga.

Berdasarkan uraian tersebut keterkaitan penelitian ini dan penelitian terdahulu yaitu, pada kedua penelitian tersebut memepunyai persamaan mengenai mekanisme pasar islam, namun pada penelitian terdahulu pembahasan tersebut lebih condong ke harga yang adil dalam pasar, sedangkan pada artikel ini membahas mengenai maslahah mursalah dalam mekanisme pasar.

3. Idris Parakkasi dan Kamiruddin, (2018), "Analisis Harga Dan Mekanisme Pasar Dalam Perspektif Islam", jenis dari penelitian ini menggunakan metode kepustakanaan atau library research, hasil dari penelitian ini yaitu, pada kaidah Islam ketentuan harga diserahkan kepada mekanisme pasar yang alamiah sesuai dengan kekuatan penawaran (suplay) dan permintaan (demand) pasar. Sistem Islam sangat mendorong harga yang adil dengan mendorong persaingan pasar yang sempurna. Untuk memenuhi harga yang adil perlu adanya moralitas (fair play), kejujuran (honesty), keterbukaan (transparancy) dan keadilan (justice). Pada kondisi tertentu untuk melalukan intervensi harga (price intervention) oleh pemerintah bila terjadi distorsi pasar, baik yang disebabkan oleh faktor alamiah maupun perilaku menyimpang dari pelaku pasar.

Berdasarkan uraian tersebut keterkaitan penelitian ini dan penelitian terdahulu yaitu, pada kedua penelitian tersebut mempunyai persamaan mengenai mekanisme pasar yang adil dalam islam, namun pada penelitian terdahulu tidak membahas mengenai maslahah mursalahnya.

\section{METODE PENELITIAN}

Pada artikel ini mendasarkan kepada studi kepustakaan (library research). Penelitian perpustakaan atau penelitian pustaka merupakan rangkaian penelitian tentang 
metode pengumpulan data perpustakaan atau objek penelitian menggali penelitiannya melalui berbagai informasi perpustakaan seperti: buku, ensiklopedi, jurnal (Nana Syaodih, 2009). Pada penelitian ini, penulis menggunakan penelitian deskriptif dengan lebih menekankan pada kekuatan analisis sumber-sumber dan data-data yang ada. Dalam hal ini penulis mengandalkan teoriteori dan konsep-konsep yang ada untuk diinterpretasikan berdasarkan tulisan-tulisan yang mengarah kepada pembahasan.

Sumber data pada penelitian ini yaitu berupa personal document sebagai sumber dasar atau data primernya. Pada hal ini data tersbut berupa buku-buku, jurnal, ensiklopedi, majalah, makalah, artikel dan lain-lain yang relevan. Sumber data tersebut yang berkaitan dengan konsepsi dan urgensi mata pelajaran manajemen pemasaran islam dengan permasalahan mengenai harga.

Teknik pengumpulan data ini dilakukan untuk memperkuat fakta dan membandingkan perbedaan atau persamaan antara teori dan praktek. Seperti pada yang penulis teliti terkait dengan masalah segmen dan target pasar dalam islam.

Analisis isi (content analysis) atau analisis isi adalah metodologi penelitian dengan menggunakan seperangkat prosedur tarik kesimpulan yang valid dari buku atau dokumen (Moleong, 2009). Berdasarkan penjelasan uraian tersebut dapat disimpulkan bahwa analisis isi adalah suatu metode riset di beberapa tahap untuk dikuasai ide dan informasi, lalu menarik kesimpulan.

\section{KONSEP DASAR}

\section{Maslahah Mursalah}

Maslahah mursalah merupakan terdiri dari dua kata yaitu maslahah dan mursalah. Maslahah mursalah secara erimologi mempunyai pengertian, bahwa upaya mengambil manfaat dan menghilangkan mudharat-nya. Dalam hal ini dapat dipahami, bahwa mashlahah mamiliki dua terma yaitu adanya manfaat (إجابي) dan menjauhkan madharat (سلبي). Terkadang maslahah dapat ditinjau dari aspek ijab-nya saja dan menjadi qorinah menghilangkan mafsada / mudharat. (Bahrudin, 2019). Asy-syaitibi merupakan salah seorang ulama' maliki mengatakan bahwa: (Syafe'i, 2007).

1. Maslahah mursalah merupakan suatu masalah yang tidak ada di dalam nash tertentu, namun masih sesuai dengan tindakan syara'.

2. Makna maslahah tersendiri diambil dari keseluruhan nash dan beberapa dalildalil, sehingga menghasilkan hukum yang pasti (qath'i).

Dari pengertian di atas dapat disimpulkan, bahwa maslahah mursalah merupakan metode untuk penggalian hukum dengan mengambil manfaat atau kemaslahatan dan menghilangkan mudharat.

Maslahah mursalah adalah logika kumpulan nash, bahkan Imam Syatibi mengatakan bahwa keberadaan dan kualitas maslahah bersifat qath'i, meski dalam mengaplikasikannya bisa jadi zhanni. Syarat yang harus dipenuhi untuk dapat menjadikan maslahah al-mursalah sebagai hujjah Menurut kalangan Malikiyyah dan Hambaliah sebagai berikut: (Muksana Pasaribu, 2014)

1. Manfaatnya sesuai dengan keinginan Syara dan sudah termasuk di dalamnya jenis pendapatan yang didukung oleh nash secara umum.

2. Manfaatnya masuk akal dan pasti, bukan hanya perkiraan, sehingga hukum dapat ditetapkan melalui maslahah al-mursalah benar-benar menghasilkan manfaatkan dan menghindari atau menolak kemudharatan.

3. kemaslahatan tersebut berkaitan dengan kepentingan banyak orang, bukan ketertarikan pribadi.

Tujuan dilakukannya maslahah mursalah merupakan sebagai alternatif 
terbaik untuk pengembangan metodemetode ijtihad, di mana Alqur'an dan Sunnah harus dipahami melalui metodemetode ijtihad dengan memberi penekanan pada dimensi maslahah. Dalam hal ini, konsep maslahah mursalah memberi keterangan bagi aturan hukum baru dan memungkinkan para ulama fikih mengelaborasi konteks masalah yang tidak ditegaskan oleh nash syara'. Seperti yang telah dikemukan oleh Asmawi (2016), seberapa besar perubahan hukum dapat dicapai melalui aplikasi konsep maslahah tergantung pada, terutama, pola penalaran hukum berbobot maslahah yang diterapkan para ulama fikih (Adinugraha, 2018).

Menurut Amir Syarifuddin maslahah mursalah mempunyai dua bentuk yaitu: (Syarifuddin, 2008).

1. Mewujudkan manfaat, pada hal ini dapat mewujudkan kesenangan atau kebaikan untuk manusia. Kesenangan dan kebaikan tersebut dapat dirasakan oleh orang yang melakukan suatu perbuatan sesuai dengan yang diperintahkan. Kesenangan dan kebaikan tersebut dirasakan langsung ketika melakukan perbuatan atau kemudian hari setelah melakukan perbuatan tersebut.

2. Menghindari ummat manusia dari kerusakan dan keburukan yang disebut dar'u al-mafasid. Pada hal ini, melindungi manusia dari kerusakan dan keburukan terhadap perbuatan yang dilarang. Kerusakan dan keburukan tersebut dapat dirasakan langsung setelah melakukan perbuatan yang dilarang ataupun ketika melakukan perbuatan yang dilarang tersebut mereka merasakan kesenangan terlebih dahulu, tetapi setelah itu mereka merasakan dampak dari perbuatannya yaitu kerusakan dan keburukan.

Effendi telah mengutip pada tulisan Abdul Wahhab Khallaf mengatakan, bahwa maslahah mursalah mempunyai beberapa syarat dalam memfungsikannya, yaitu: (Effendi, 2014).

1. Maslahat tersebut berupa maslahat yang hakiki, maslahat yang benar-benar akan mendatangkan manfaat atau menolak mudharatan. Dalam hal ini bukan hanya sebuah dugaan untuk mepertimbangkan adanya kemanfaatan tanpa melihat akibat negatif yang ditimbulkannya.

2. Sesuatu yang dianggap maslahat tersebut merupakan kepentingan umum bukan kepentingan pribadi semata.

3. Sesuatu yang dianggap maslahat tersebut tidak bertentangan dengan $\mathrm{Al}$ Qur'an, As-Sunnah, Ijma' ataupun Qiyas.

Macam-macam Maslahah mursalah apabila dilihat dari segi eksistensi atau keberadaannya menurut syara', yaitu: (Peristiwo \& Abdul Hadi, 2019).

1. Maslahah Al-mu'tabarah, merupakan maslahah yang sudah diakui keberadaannya dan sudah terdapat di dalam nash. Dalam hal ini, maslahah tersebut sudah diakui oleh syara' dan dalam kemaslahatan tersebut terdapat dalil yang menjadi dasar bentuk dan jenisnya.

2. Maslahah Al-Mulghah, merupakan suatu perkara yang dianggap maslahah bagi pikiran namun bertolak belakang dengan syara' atau bertentangan dengan ketentuan dalil.

3. Maslahah Al-Mursalah, pada maslahah ini tidak terdapat dalil yang mendukung dan tidak ada yang menolaknya. Maslahah mursalah ini merupakan suatu maslahah yang berkembang berdasarkan pengaruh kondisi maupun tempat umat manusia. maslahah mursalah tersebut dibagi menjadi dua, yaitu: (Dahlan, 2011).

a. Maslahah Al-gharibah, pada maslahah ini hanya terdapat di dalam teori namun tidak ditemukan kesaksian syara' yang menerima atau menolaknya. 
b. Maslahah Al-Mula'imah, pada maslahah ini meskipun tidak terdapat nash yang mengakui, namun sesuai dengan tujuan syara' secara umum. Pada hal ini, tujuan syara' tersebut ada dalam Al-Qur'an, Hadits, Ijma' muapun Qiyas yang dapat dipahami isi kandungan dan maknanya.

Berdasarkan dari segi kandungan mashlahah, Ushuliyyun membagi menjadi dua bagian: (Misbahuddin, 2013)

1. Maslahat ammah (maslahat publik).

Maslahat Ammah yaitu kemaslahatan yang menyangkut kepentingan publik. Kemashlahatan itu bukan berarti untuk kepentingan seluruh orang, namun mampu berupa bentuk kepentingan dominan umat atau kebanyakan umat.

2. Maslahat khasshah (maslahat individu). Maslahat Khasshah yaitu kemaslahatan pribadi seperti kemaslahatan yang berkaitan dengan pemutusan hubungan perkawinan seseorang yang dinyatakan hilang. Pentingnya pembagian kedua kemaslahatan berkaitan dengan prioritas mana yang harus diutamakan apabila kemaslahatan umum itu berbenturan dengan kemaslahatan khusus. Dalam perbenturan dari kedua kemaslahatan ini, Islam mendahulukan kemaslahatan umum dari pada kemaslahatan yang sifatnya pribadi.

Pada maslahah mursalah terdapat beberapa ulama' yang mempunyai pendapat berbeda dalam bidang muamalat. Ulama' tersebut berasal dari sebagian kalangan Syafi'iyah, Hanafiyah dan Zahiriyah. Maslahah mursalah tidak diakui oleh kalangan tersebut sebagai landasan hukum. Adapun alasan-alasan kalangan tersebut menolak maslahah mursalah, sebagai berikut: (Effendi, 2014).

1. Hukum yang sudah ditetapkan oleh Allah SWT dan Rasulullah SAW merupakan segala bentuk untuk kemaslahatan umat manusia. Sehingga, apabila maslahah mursalah digunakan sebagai landasan penetapan hukum, maka sama saja menganggap Al-Qur'an dan As-Sunnah belum lengkap dan masih terdapat maslahah yang tidak tertampung di dalamnya.

2. Apabila maslahah mursalah dibenarkan sebagai landasan hukum, maka akan membuka peluang bagi pihak yang mempunyai keinginan menetapkan hukum berdasarkan keinginannya sendiri, dengan alasan demi kemaslahatan bersama. Dalam artian disalahgunakan oleh pihak-pihak tertentu.

Selain beberapa alasan penolakan dari ulama' tersebut, terdapat beberapa kalangan yang menerima maslahah mursalah sebagai landasan penetapan hukum. Ulama' tersebut berasal dari sebgaian kalangan Syafi'iyah, Hanabilah, dan Malikiyah. Alasan-alasan uluma' tersebut, yaitu:

1. Syariat islam yang diturunkan berdasarkan Al-Qur'an dan As-sunnah bertujuan untuk kemaslahatan dan kebutuhan umat manusia. Manusia mempunyai kebutuhan yang berbeda seiring berkembangknya zaman. Dalam hal ini, segala sesuatu yang dianggap sebagai maslahah dan bisa dijadikan landasan hukum apabila tidak bertentangan dengan Al-Qur'an dan AsSunnah.

2. Para sahabat berijtihad menganggap sah maslahah mursalah sebagai landasan hukum tanpa ada bantahan dari seseorangpun.

\section{Mekanisme Pasar}

Azizah mengutip pada Sudarsono mengatakan, bahwa pasar merupakan suatu penggerak masyarakat untuk memenuhi kebutuhan-kebutuhan hidupnya. Islam mengatur pasar agar tidak merugikan satu dengan yang lainnya. pada hal ini, keterlibatan produsen, konsumen maupun pemerintah sangat penting dalam 
menyamakan pendapat mengenai harga suatu barang yang berlaku (Azizah, 2012). Apabila hal tersebut dapat terlaksana, maka mekanisme pasar yang sesuai dengan syariat islam akan berdampak pada kesejahteraan masyarakat. Menurut Marthon (2008) mengatakan, bahwa pasar mempunyai tujuan untuk mencari ridho Allah dalam mewujudkan kesejahteraan maupun kemaslahatan hidup (Azizah, 2012).

Kekuatan pasar dalam islam dapat diukur dari segi permintaan dan penawaran, seperti yang telah dikutip oleh Rahmi pada P3EI (2011) yang menjelaskan bahwa, permintaan merupakan keinginan yang muncul dari konsumen. faktor yang mempengaruhi permintaan yaitu, harga produk, penghasilan konsumen, dan selera konsumen. sedangkan penawaran merupakan kesediaan barang dalam pasar. (Rahmi, 2015)

Ibnu Taimiyah mengatakan bahwa mekanisme pasar dalam islam mempunyai beberapa ciri khas, di antaranya: (Aravik, 2016).

1. Bebas keluar masuk pasar.

2. Adanya informasi-informasi yang cukup yang berkaitan dengan kekuatan pasar dan barang-barang yang dijual.

3. Unsur yang berkaitan dengan monopolistik harus dihilangkan dari pasar. Pemerintah diperbolehkan melakukan monopoli apabila terjadi kecurangan dalam pasar.

4. Kenaikan dan turunnya harga dalam pasar terjadi akibat naik turunnya suplay dan demand.

5. Adanya homogenitas dan standarisasi produk supaya terhindar dari penipuan, kecurangan maupun pemalsuan tentang kualitas produk.

6. Terhindar dari penyimpangan terhadap kebebasan ekonomi yang jujur, seperti kecurangan dalam timbangan atau takaran, ukuran dan niat yang buruk dalam jual beli.
Harga mempunyai arti sejumlah uang sebagai nilai tukar guna untuk mendaptkan suatu barang atau jasa. Pada syariat islam diharuskannya menentukan harga yang adil. Harga yang adil tersebut merupakan nilai yang dibayarkan oleh konsumen sesuai dengan objek yang diberikan oleh penjual (Amalia, 2013). Menurut Rachmat Syafe'i yang telah dikutip oleh Prakkasi, mengatakan, bahwa harga hanya terjadi pada akad, yaitu sesuatu yang direlakan dalam akad, baik lebih sedikit, lebih besar, atau sama dengan nilai barang. harga tersebut merupakan sebagai alat tukar yang diridhai oleh penjual maupun pembeli yang berakad. (Parakkasi \& Kamiruddin, 2018).

Menurut ulama' Fiqih merumuskan harga sebagai the price of the equivalen. Yang dimaksud degan harga sepadan tersebut merupakan keadaan pasar yang kompetitif. (Karim, 2002). Harga yang baik dapat menentukan keseimbangan pasar. Harga tersebut dapat mencerminkan kesukarelaan antar produsen dan konsumen. Keseimbangan harga dalam pasar terkadang tidak sesuai dengan kepentingan masyarakat secara menyeluruh, baik dikarenakan harga tersebut relatif sangat tinggi, rendah maupun faktor proses penentuan harga yang tidak wajar. (Khoiruddin, 2010).

Melonjaknya harga dalam pasar dapat terjadi akibat tidak tersedianya barang di pasar. Hal ini di akibatkan karena faktorfaktor oknum tertentu yang menimbun barang. Pada kasus seperti ini, harus dilakukannya penegakan hukum dengan menindak lanjuti pelaku untuk mengeluarkan barangnya ke pasar. Selain itu, tingginya harga dalam pasar dapat disebabkan kurangnya penawaran. Hal tersebut dapat dilakukan dengan mengeluarkan barang-barang yang ada di gudang negara ke pasar atau mendatangkan komoditi dari daerah produksinya. (Saleh, 2011). 
Penyebab perubahan harga dalam pasar dibagi menjadi dua macam, yaitu: (Khoiruddin, 2010).

1. Genuine Factors, faktor-faktor yang bersifat ilmiah. Intervensi pasar dilakukan untuk menstabilkan harga pasar. Hal ini dilakukan dengan mempengaruhi posisi suplay dan demand agar terbentuknya harga yang wajar.

2. Non Genuine Factors, faktor-faktor yang disebabkan oleh ketidakseimbangnya pasar pada mekanisme pasar bebas. Hal yang perlu dilakukan dalam hal ini yaitu, menghilangkan penyebab ketidakseimbangan pasar tersebut dan menentapkan harga. Sehingga mekanisme pasar bebas dapat berjalan normalkembali.

Menurut Ibnu Taimiyah terdapat beberapa faktor yang mempengaruhi tingkat harga dan permintaan, yaitu: (P3EI, 2013).

1. Keinginan orang yang berbeda-beda pada produk yang ingin dibeli. Perbedann ini berdasarkan produk tersebut berlimpah atau langka. Seseorang lebih suka membeli produk langka dari pada yang berlimpah.

2. Jumlah demand akan memperngaruhi harga suatu produk. Apabila jumlah permintaan suatu barang tinggi, maka harga yang berlaku akan relatif tinggi dibandingkan ketika permintaan cenderung menurun.

3. Harga yang berlaku dipengaruhi oleh kuat atau lemahnya terhadap suatu produk tersebut. Apabila kebutuhan suatu produk kuat, maka harga yangb berlaku cenderung lebih tinggi dibandingkan dengan kebutuhan lemah.

4. Kualitas pembeli mempengaruhi harga yang berlaku. Apabila pembeli tersebut merupakan dari kalangan orang kaya dan dapat dipercaya untuk membayar kewajibannya, maka kemungkinan orang tersebut mendapatkan tingkat harga yang lebih rendah dibandingkan dengan orang yang tidak dapat dipercaya.

5. Jenis uang yang digunakan untuk transaksi jual beli tersebut dapat mepengaruhi harga. Seperti keika uang yang digunakan tersebut dapat diterima secara umum, maka kemungkinan harga akan lebih rendah jika dibandingkan dengan uang yang tidak dapat diterima secara umum.

Intervensi pasar tersebut mempengaruhi harga yang berlaku dalam pasar, harga tersebut dapat terjadi akibat faktor alamiah dan non alamiah. Pada umumnya, pemerintah melakukan kebijakan dalam menentukan harga dan melakukann kebijakan mengenai permintaan dan penawaran. Pemerintah melakukan intervensi dari sisi permintaan dan penawaran apabila ketidak seimbangan pasar tersebut akibat faktor alamiah, dan apabila ketidak seimbangan pasar tersebut dikarenakan faktor non alamiah pemerintah melakukan kebijakan dengan intervensi harga di pasar. (Saleh, 2011).

Pasar yang dapat menghasilkan harga yangh adil bagi penjual maupun pembeli dapat dikatakan sebagai pasar yang bersaing dengan sempurna. Apabila mekanisme pasar terganggu, maka harga adil yang berlaku di dalam pasar tidak akan tercapai. Harga adil yang berlaku mendorong para pelaku pasar untuk bersaing secara sempurna. (Parakkasi \& Kamiruddin, 2018).

\section{PEMBAHASAN DAN DISKUSI \\ Maslahah Mursalah Dalam Mekanisme Pasar}

Hakikat kemaslahatan merupakan segala bentuk dan kemanfaatan dunia maupun akhirat. Seuatu aktifitas ekenomi dapat dikatakan maslahat apabila memenuhi dua unsur, yaitu kepatuhan syari'ah (halal) dan bermanfaat serta membawa kebaikan untuk seluruh umat manusia. kemaslahatan 
tersebut juga tidak menimbulkan kerugian atau mudharat pada salah satu aspek. (Mursal, 2018).

Pada zaman Rasulullah harga dalam pasar pernah terjadi lonjakan yang sangat tinggi. Seperti yang telah disampaikan oleh Anas RA, yaitu:

"Harga melambung pada zaman Rasulullah saw. Masyarakat mengadukan hal itu kepada Rasulullah dengan berkata: " $y a$ Rasulullah harga telah melam-bung, tolonglah tetapkan harga". Rasulullah saw. menjawab: "Sesungguhnya Allah-lah yang berhak menetukan harga, yang menahan, melapangkan dan memberi rezeki. Aku sangat berharap bahwa kelak aku menemui Allah dalam keadaan tidak seorang pun dari kamu menuntutku tentang kezaliman dalam darah maupun harta (ad-Da-rimi, t.t.: 78)."

Hadits tersebut menjelaskan bahwa, Rasulullah tidak menentukan harga yang berlaku di pasar. Harga yang berlaku berdasarkan mekanisme pasar yang alamiah. Rasulullah menolak untuk menetapkan harga karena Allah lah yang melakukan semuanya. Pada saat itu harga yang berlaku, suplay maupun demand merupakan kehendak dari Allah. Seperti yang telah dikutip Fahlefi dalam tulisan Marthon mengatakan, bahwa pada zaman dahulu para Sahabat meminta Nabi Muhammad SAW untuk melakukan intervensi harga, namun pada saat itu Nabi Muhammad SAW menolak untuk melakukannya. (Fahlefi, 2015).

Pada zaman Rasulullah menolak melakukan intervensi harga dikarenakan harga yang berlaku pada pasar berdasarkan mekanisme alami. Rsulullah menganggap pemerintah tidak punya wewenang dalam menetapkan harga yang berlaku pada saat itu. Harga tersebut berdasarkan suplay dan demand bukan karena kesewenangan oknum-oknum tertentu. Mekanisme pasar pada ketentuan Allah bahwa perniagaan harus dilakukan secara baik dan benar dengan dasar rasa suka sama suka. Seperti ayat dalam Al-Qur'an,

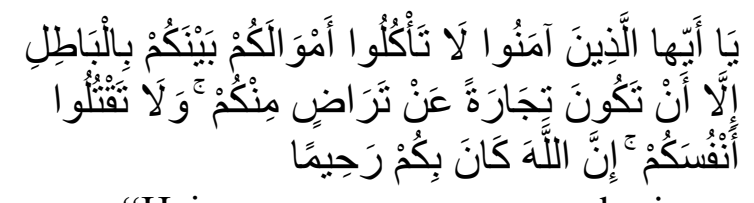

"Hai orang-orang yang beriman, janganlah kamu saling memakan harta sesamamu dengan jalan yang batil, kecuali dengan jalan perniagaan yang berlaku dengan suka sama-suka di antara kamu. Dan janganlah kamu membunuh dirimu; sesungguhnya Allah adalah Maha Penyayang kepadamu. (Q.S. AnNisa' (4): 29)"

Pada persaingan dalam islam perlu menegakkan nilai-nilai moralitas di antaranya, persaingan yang sehat, kejujuran, keterbukaan, dan keadilan (P3EI, 2013). Berdasarkan nilai-nilai moral tersebut Rasulullah tidak melakukan intervensi harga. Rasulullah melarang praktek perniagaan yang merugikan orang lain atau mengganggu mekanisme pasar yang berlaku.

Ibnu taimiyah mengatakan bahwa pada mekanisme pasar islam merupakan pasar bebas, sehingga kekuatan pasar ditentukan oleh permintaan dan penawaran. Kenaikan harga dalam pasar tidak selalu disebabkan oleh kecurangan oleh oknum tertentu atau pedagang. Naik turunnya harga dapat disebabkan oleh defisiensi produksi, turunnya minat beli konsumen dan tenakanan pasar. (Aravik, 2016).

Ibnu Taimiyah memperbolehkan pemerintah melakukan intervensi harga pada beberapa kondisi tertentu seperti:

1. Kebutuhan masyarakat umum akan barang atau jasa

2. Terjadinya monopoli atau penipuan. Hal ini untuk mengantisipasi tindakan 
negatif atau yang membahayakan. Seperti dilakukannya penimbunan barang oleh oknum tertentu.

3. Terjadinya pemboikotan. Distribusi barang yang tidakan dilakukan secara merata hanya berfokus dengan salah pihak. Penetapan harga dalah hal ini, menghindari penjual untuk menetapkan harga dengan semena-mena.

4. Terjadinya kolusi antara penjual. Dalam hal ini, pedagang melakukan kesepakatan antara pedagang lainnya dengan menentukan harga penjualan di bawah pasaran. Intervensi harga dilakukan untuk menghindari terjadinya fluktuasi harga barang yang melonjak.

Penetapan harga tersebut wajib dilakukan ketika harga mengalami kenaikan yang sangat tinggi. Kenaikan harga terjadi dapat diakibatkan oleh kedzaliman spekulan sehingga terjadinya ketidaksempurnaan pasar. Berdasarkan kasus tersebut pemerintah harus menetapkan harga yang adil. Tindakan pemerintah kepada spekulan tersebut yaitu dengan memaksa spekulan menjual barangnya dengan harga yang setara, dan melakukan tindakan hukum kepada spekulan. (Rozalinda, 2016).

Kasus lain terjadinya ketidak seimbangan pasar akibat faktor alamiah atau suplay dan demand. Pada hal ini pemerintah melakukan intervensi pasar agar pasar dapat kembali seimbang dengan dilakukannya impor barang. Hal tersebut dilakukan karena adanya penurunan produksi kebutuhan yang diakibatkan oleh harga kebutuhan pokok naik sedangkan permintaan mengalami kenaikan dan produksi menurun.

Menurut islam Negara memiliki hak ikut andil dalam kegiatan ekonomi masyarakat. Negara dapat melakukan kegiatan pengawasan maupun mengatur kegiatan-kegiatan ekonomi (Nawawi, 2009). Pemerintah mengeluarkan undang-undang mengenai bentuk intervensi harga, diantaranya: (Rozalinda, 2016).
1. Pemerintah terkadang menentukan suatu harga minimum (price floor). Dalam hal ini pemerintah menentukan harga dengan tujuan melindungi produsen.

2. Pemerintah menentukan harga atau upah maksimum (price ceiling), pemerintah melakukan price ceiling ini bersifat memihak pada konsumen.

3. Pemerintah melakukan price fixing atau menetapkan harga pada komoditaskomditas tertentu. Seperti BBM

Peran pemerintah pada mekanisme pasar sangat penting sebagai pengawas, regulator maupun mengatur mekanisme pasar agar harga yang berlaku tetap seimbang. Harga yang seimbang tersebut tidak menimbulkan dampak negatif untuk penjual maupun pembeli. Regulasi harga yang dilakukan oleh pemerintah mempunyai tiga fungsi, yaitu: (Rahmi, 2015).

1. Fungsi ekonomi, fungsi ini yang mengenai peningkatan produktivitas dan peningkatan pendapatan masyarakat miskin melalui alokasi dan relokasi sumber daya ekonomi.

2. Fungsi sosial, pada fungsi ini yaitu meminimalisir kesenjangan antara masyarakat miskin dan masyarakat kaya.

3. Fungsi moral, fungsi ini merupakan upaya untuk menegakkan nilai-nilai islam dan aktivitas perekonomian.

Pendapat Ibnu taimiyah tersebut bukan berarti bertentangan dengan Rasulullah SAW. Ibnu Taimiyah membolehkan pemerintah melakukan intervensi harga dengan tujuan untuk keseimbangan harga pasar. Harga yang seimbang dalam pasar akan meciptakan kebaikan atau manfaat untuk penjual maupun pembeli.

Ibnu Taimiyah memperbolehkan pemerintah melakukan intervensi harga sendiri bertujuan untuk kemaslahatan umat manusia dan menjegah terjadinya kedzaliman. Intervensi harga tersebut 
termasuk dalam maslahah mursalah karena di dalam intervensi harga tersebut mengambil suatu kebaikan atau manfaat dan menghilangkan mafsadat atau mudharat.

Tujuan lain dilakukannya intervensi harga menurut IbnuQuddamah al Maqdisi yaitu, intervensi harga menyangkut kepentingan umat manusia, mencegah penjual mengambil keuntungan di atas harga normal yang berlaku di pasar, dan untuk melindungi kepentingan masyarakat yang lebih luas.

Apabila dihubungkan dengan konsep maslahah mursalah, intervensi harga tersebut masuk kedalam bagian maslahah al-mursalah. Maslahah tersebut berkembang berdasarkan kondisi maupun tempat. Maslahah pada intervensi harga tersebut boleh dilakukan pada masa sekarang karena mengantisipasi hal-hal yang dapat berdampak negatif pada penjual maupun pembeli.

Pada zaman Rasulullah SAW tidak dilakukannya intervensi harga karena penjual dan pembeli menjunjung tinggi akan nilai-nilai moral. Pada masa tersebut kenaikan harga murni dikarenakan suplay dan demand. Sehingga Rasulullah SAW menganggap pemerintah tidak berhak ikut campur tangan dalam menentukan harga.

Pada masa sekarang kenaikan harga bukan hanya dikarenakan suplay dan demand semata. Harga tersebut naik tidak menutup kemungkinan karena dampak dari oknum yang menimbun barang atau terjad karena kolusi antar penjual. Sehingga Ibnu Taimiyah memperbolahkan dilakukannya intervensi harga pada saat-saat tertentu. Pernyataan Ibnu Taimiyah tersebut bertujuan untuk keseimbangan mekanisme pasar dan kebaikan penjual maupun pembeli.

Seperti contoh dalam kasus ekonomi di Indonesia. Harga dalam pasar Indonesia sering terjadi lonjakan harga pada kebutuhan pokok. Kelonjakan harga tersebut disebabkan oleh ketergantungannya terhadap komoditas impor. Apabila dikaitkan dengan pemikiran Ibnu Taimiyah, ketika harga kebutuhan pokok naikyang disebabkan oleh adanya monopoli atau manipulasi oleh sekelompok orang, maka pemerintah diwajibkan untuk melakukan intervensi harga. (Farma, 2019).

\section{KESIMPULAN}

Hakikat kemaslahatan merupakan segala bentuk dan kemanfaatan dunia maupun akhirat. Seuatu aktifitas ekenomi dapat dikatakan maslahat apabila memenuhi dua unsur, yaitu kepatuhan syari'ah (halal) dan bermanfaat serta membawa kebaikan untuk seluruh umat manusia.

Rasulullah menolak melakukan intervensi harga pada zamannya. Harga yang berlaku di pasar berdasarkan mekanisme alamani. Rasulullah beranggapan bahwa pemerintah tidak mempunyai wewenang dalam menetapkan harga yang berlaku di pasar. Harga tersebut murni berdasarkan suplay dan demand bukan karena kesewenangan oknum-oknum tertentu.

Ibnu Tamiyah memperbolehkan pemerintah melakukan intervensi harga pada masa kini. Intervensi harga Diperbolehkannya dalam kondisi tertentu, seperti terjadinya kolusi anatar penjual, monopoli, dan terancamnya kebutuhan masyarakat. Tujuan dari intervens harga tersebut merupakan untuk kemaslahatan umat manusia dan untuk menjaga agar tidak terjadi hal-hal yang negatif.

\section{DAFTAR PUSTAKA}

(P3EI), P. P. D. P. E. I. (2013). Ekonomi Islam. PT. Rajagrafindo Persada.

Adinugraha, H. H. (2018). Jurnal Ilmiah Ekonomi Islam , 4 ( 01 ), 2018 , 6375 Al-Maslahah Al-Mursalah dalam Penentuan Hukum Islam. 4(01), 6375.

Amalia, E. (2013). Mekanisme Pasar dan 
Kebijakan Penetapan Harga Adil Dalam Perspektif Ekonomi Islam. Jurnal: Al-Iqtishad, Vol. V(1).

Amir Syarifuddin. (2008). Ushul Fiqh (jilid

2). Kencana Prenada Media Group.

Aravik, H. (2016). Ekonomi Islam. Empatdua.

Asmawi. (2014). Konseptualisasi Teori Mașlahahah. Salam: Jurnal Sosial Dan Budaya Syar'i, Vol. 1, No.

Asriaty. (2015). Penerapan Mashlahah Mursalah Dalam Isu-Isu Kontemporer. Madania, Vol. 19(No. 1), 119-129.

Azizah, M. (2012). Harga Yang Adil Dalam Mekanisme Pasar Dan Peran Pemerintah Dalam Perspektif Islam. Unisia, Vol. Xxxiv.

Bahrudin, M. (2019). Ilmu Ushul Fiqh. CV. Anugrah Utama Raharja.

Dahlan, A. R. (2011). Ushul Fiqh. AMZAH.

Effendi, S. (2014). Ushul Fiqh. Kencana Prenadamedia Group.

Fahlefi, R. (n.d.). Implementasi ma ș la ḥ ah dalam kegiatan ekonomi syariah. JURIS, Volume 14,(137).

Farma, J. (2019). Mekanisme Pasar dan Regulasi Harga: Telaah Atas Pemikiran Ibnu Taimiyah. 13(2), 182-193.

Hadi, H. P. \& A. (2019). Konsep AlMaslahah Al-Mursalah Dalam Perspektif Ekonomi Pada Era Revolusi Industri 4.0. Al-Ahkam, Vol. 15 No.

Ilyas, R. (2015). Konsep Mashlahah Dalam Konsumsi Ditinjau Dari Perspektif Ekonomi Islam. Jurnal Perspektif Ekonomi Darussalam, 1, 9-24.

Karim, A. A. (2002). Ekonomi Mikro Islami. IIIT Indonesia.
Khoiruddin, O. (2010). Pasar islam. 2(2), 61-72.

Misbahuddin. (2013). Ushul Fiqh I. Alauddin University Press.

Moleong, L. J. (2009). Metodologi Penelitian Kualitatif. PT. Remaja Rosdakarya.

Muksana Pasaribu. (2014). Maslahat Dan Perkembangannya Sebagai Dasar Penetapan Hukum Islam. Justitia, Vol. 1(No. 04), 350-360.

Mursal. (2018). Signifikansi Maslahat Dalam Supply And Demand: Analisis Makna Sejahtera Perspektif Ekonomi Syariah. Jurnal Kajian Dan Pengembangan Umat, 1(1), 1424.

Nana Syaodih. (2009). Metode Penelitian Pendidikan. PT. Remaja Rosdakarya.

Nawawi, I. (2009). Ekonomi Islam: Perspektif Tepri, Sistem Dan Aspek Hukum. CV. Putra Media Nusantara.

Parakkasi, I., \& Kamiruddin, K. (2018). Analisis Harga Dan Mekanisme Pasar Dalam Perspektif Islam. LAA MAISYIR : Jurnal Ekonomi Islam,

Rahmi, A. (2015). Mekanisme Pasar dalam Islam. Jurnal Ekonomi Bisnis Dan Kewirausahaan, 4(2), 177-192.

Rozalinda. (2016). Ekonomi Islam: Teori Dan Aplikasi Pada Aktivitas Ekonomi. PT. Rajagrafindo Persada.

Saleh, M. (n.d.). Pasar Syari' Ah Dan Keseimbangan Harga. Media Syariah, Vol. XIII, 21-36.

Syafe'i, R. (2007). Ilmu Ushul Fiqh. Pustaka Setia. 